\title{
Progress of Research on Spatzle and Toll Signaling Pathway in Insects
}

\author{
Ji Liu ${ }^{1}$, Jinmei $\mathrm{Wu}^{1,2, *}$ \\ ${ }^{1}$ College of Biotechnology, Jiangsu Universitiy of Scence and Technology, Zhenjiang, China \\ ${ }^{2}$ The Sericultural Research Institute, Chinese Academy of Agricultural Sciences, Zhenjiang, China
}

\section{Email address:}

1141756029@qq.com(Ji Liu),jwuus@hotmail.com(Jinmei Wu)

\section{To cite this article:}

Ji Liu, Jinmei Wu. Progress of Research on Spatzle and Toll Signaling Pathway. American Journal of Bioscience and Bioengineering. Vol. 3, No. 5, 2015, pp. 134-141. doi: 10.11648/j.bio.20150305.28

\begin{abstract}
Insects are the most diverse group of animals on Earth. Contrary to the vertebrates, insects have no acquired immunity, and to resist the invasion of external microbes, they can only rely on their own innate immunity. Innate immunity is the first line of defense in organisms. When microbia invade, a group of germline-encoded pattern recognition receptors (PRR) can recognize and bind to conserved pathogen-associated molecular pattern (PAMP), and then the host activates multiple signaling pathways to induce the expression of antimicrobial peptides (AMP). Toll signaling pathway is the most actively studied signaling pathway. Toll and its ligand Spatzle play an important role in Toll pathway of the immune response. The structure and function of spatzle in Drosophila, Manduca sexta, Bombyx mori and other insects have been reviewed in this article. The results suggested that spatzle from different insects have conserved structure and similar activation mechanism and plays an important role in the initiation of Toll signaling pathway. This provides a theoretical basis for research on spatzle and Toll signaling pathway in other insects.
\end{abstract}

Keywords: Insects, Innate Immunity, Humoral Immunity, Spatzle, Toll Pathway

\section{昆虫Spatzle及To11信号通路研究进展}

\author{
刘雯 ${ }^{1}$, 吴金美 ${ }^{1,2, *}$ \\ ${ }^{1}$ 生物技术学院, 江苏科技大学, 镇江, 中国 \\ 贵业研究所, 中国农业科学院, 镇江, 中国
}

\section{邮箱}

1141756029@qq. com（刘雯），jwuus@hotmail.com（吴金美）

\begin{abstract}
摘要：昆虫是地球上种类最多的动物群体。与脊椎动物不同，昆虫没有获得性免疫，只能依靠自身的天然免疫抵御外 界微生物的入侵。天然免疫是机体的第一道防线。微生物入侵时, 一组种系编码的模式识别受体 (PRR) 可以识别并结 合到保守的病原体相关分子模式 (PAMP) 上, 通过一系列的信号传导产生抗菌肽最终消灭微生物。Tol1信号通路是目前 研究最多的一条信号通路, Tol1和其配体Spatzle在Tol1通路免疫应答中发挥重要作用。本文对果蝇、烟草天蛾、家蚕 和其他昆虫的 spatzle结构和功能进行系统的阐述, 发现它们具有相似的结构和激活机制并在Tol1信号通路起始发挥重 要作用, 这为研究其他昆虫的spatzle和Tol1通路提供了理论依据。
\end{abstract}

关键词: 昆虫, 先天性免疫, 体液免疫, Spatzle, Toll通路 


\section{1. 引言}

天然免疫和获得性免疫系统是多细胞生物防御系统 的两个主要组成部分。天然免疫广泛存在于多细胞有机生 物体, 与生俱来, 无需抗原预先刺激就能快速发挥其效应 功能。其主要成分包括颗粒细胞、巨噬细胞、天然杀伤细 胞等天然免疫细胞, 补体、抗菌肽、防卫素等天然免疫分 子，以及皮肤、肠道等天然防卫屏障 [1]。昆虫体内缺乏 高等脊椎动物所具有的获得性免疫系统, 只能依赖发达的 天然免疫系统抵抗细菌、真菌、病毒等外源病原物的侵染 [2]。在昆虫中, 天然免疫一方面是微生物入侵后激活血 细胞并参与吞噬和包埋病原体 [3], 另一方面是脂肪体产 生并分泌一系列的抗菌肽应答微生物的入侵。天然免疫是 控制免疫应答的第一道防线, 它也可以深刻地影响获得性 免疫应答的建立 [4]。在天然免疫反应中, 微生物入侵时, 一组种系编码的模式识别受体 (PRR) 可以识别并结合到 保守的病原体相关分子模式 (PAMP) 上, 如细菌和真菌, 但不能结合宿主细胞本身 [5]。天然免疫系统由体液免疫 和细胞免疫组成。细胞免疫应答主要包括血细胞介导的反 应, 如结节形成、吞噬和黑化包埋; 而体液免疫反应主要 包括抗菌肽 (AMP) 的合成和酚氧化酶原系统的激活。为 了应对微生物感染, 宿主激活各种信号通路以诱导免疫效 应分子 (各种转录因子和抗菌肽) 的表达, 其中主要的信 号通路有JAK/STAT、Tol1和IMD通路。

\section{Spatzle的研究进展}

\section{1. 果蝇的spatzle}

果蝇Spatzle家族共有 5 个成员（Spz2-6），这五个都 是编码含有神经营养因子样胱氨酸结结构域的蛋白质。此 外, 大多数与原型spatzle基因共享一个有特性的内含子外显子结构, 一个 67 个核苷酸的内含子位于半胱氨酸结结 构域内。这表明这五个基因由同一个古基因复制产生, 基 因产物可能产生结合To11受体的活性配体。只有Spz4在幼 虫和成虫强烈表达, 因此可能参与由To11-5介导的辅助抗 真菌响应。与此相反, Spz6在胚胎发育后期表现出一个复 杂的空间和时间上的调节表达模式。因此, spatzle家族 信号分子可能在发育和免疫功能的其他方面有重要的作 用 [6]。此外, spatzle在细胞凋亡缺陷果蝇中应答内源性 危险信号中也发挥重要作用 [7]。spatzle蛋白在果蝇中是 神经生长因子样配体的前体, 它规定了果蝇胚胎的背腹轴 而且在成体果蝇应答真菌和细菌感染的起始发挥作用, 和 凝固蛋白原和人的神经生长因子序列同源, 两个半胱氨酸 残基基序的二硫键形成环形二硫桥。成熟Spatzle连接到 其受体Tol1导致细胞质Tol1/白介素-1受体结构域的受体 二聚化和自身磷酸化。已经有研究表明, NH2 - 末端结构 域是天然展开的, 具有对Easter的调节效果, 并保持结合 到下面的活化裂解的胱氨酸结域。C端NGF样结构域又叫胱 氨酸结结构域, 每个单体有 7 个半胱氨酸, 可能涉及通过 二硫键的二聚化 [8]。

在没有信号的条件下, spatzle的前结构域掩盖了 spatzle的呈疏水性的区域, 是不活跃的。表明前结构域序
列是无序的, 作用是阻止细胞因子和它的受体Tol1相互作 用。该蛋白水解导致的构象改变暴露了结合Tol1受体关键 区域。在To11的前域有一个呈现出两亲性螺旋的保守序列 可能结合到spatzle的疏水区域。这一机制的激活与當 (4 亿年来变化不大的无脊椎动物）的凝血因子 coagulogen 有着惊人的相似 [9]。有活性的spatzle 是激活Toll信号通 路诱导产生抗菌肽所必需的。在果蝇中, spatzle的激活 有两种途径。胚胎发育早期, Easter (一种丝氨酸蛋白酶) 将前Spatzle裂解成活性的Spatzle [10]; 原肠胚缺陷基因、 snake和easter, 编码丝氨酸蛋白酶, 在胚胎的背腹模式 中是激活spatzle必须的 [11]。此外, 磺酸化的管状蛋白 Pipe也可以独立地激活easter [12]（图1）。鞘脂样蛋白 Seele活性对toll的spatzle介导激活是可有可无的, 但对 原肠胚缺陷基因, snake, easter在背腹分化中发挥作用 是必须的。Seele的功能对easter从发育中的胚胎分泌到 卵周隙和easter的激活是必需的。Seele蛋白驻留在胚盘 的内质网, 这表明Seele在easter分泌到围卵腔中起转移 作用, 是其加工和功能的前提 [13]。

真菌和革兰氏阳性菌的感染也可以激活spatzle。真 菌感染时, GNBP 家族的GNBP-3识别到真菌细胞壁上的 $\beta$ -1, 3-葡聚糖, 革兰氏阳性菌入侵时, PGRP-SA, PGRP-SD, GNBP- 1 作为识别受体来识别革兰氏阳性菌细胞壁中的赖 氨酸型肽聚糖 [14], 然后激活模块化丝氨酸蛋白酶 (ModSP), 接着激活革兰氏阳性菌特异性丝氨酸蛋白酶 (Grass), 此外, 另外三种丝氨酸蛋白酶sphinx1/2, spirit 和spheroide也是激活spatzle必须的 [15-17]。真菌分泌 的真菌毒性因子PR1 和革兰氏阳性菌毒性因子可以直接 激活 PSH [15] [18]。接着激活Spatzle的激活酶 (SPE) 从 而裂解前Spatzle蛋白形成活性的spatzle（如图1）。果 蝇丝氨酸蛋白酶抑制剂Necrotic 特异性抑制细胞外丝氨 酸蛋白酶级联激活Toll配体, spatzle。Necrotic带有多 聚谷氨酰胺延伸氨基末端至核心丝氨酸蛋白酶抑制剂的 结构。激活Toll途径上游的任一分支后诱导丝氨酸蛋白酶 抑制剂的 $\mathrm{N}$-末端裂解。表明, Necrotic的氨基末端延伸的 裂解可能在初始免疫应答中调节 spatzle的激活 [19]。遗 传和生化分析表明, 一种新颖的UDP-半乳糖转运体 Senju 的宿主糖基化控制调节spatzle转化为活性形式 [20]。

\section{2. 烟草天蛾的spatzle}

烟草天蛾的Spatzle-1由于选择性剪接形成两个不同 cDNA, proSpatzle $-1 B$ 的前结构域插入 10 个氨基酸残基, 而 proSpatzle-1A中则不存在。proSpatzle $-1 \mathrm{~A}$ cDNA编码一个 $32.7 \mathrm{kDa}$ 的多肽, 与果蝇和家蚕Spatzle-1分别有 $23 \%$ 和 $44 \%$ 的同一性的。重组proSpätzle-1A是一个二硫键连接的同型 二聚体 $[22]$ 。

烟草天蛾proSpatzle -1 A的裂解激活需要丝氨酸蛋白 酶的作用, 已经在烟草天蛾的血淋巴中确定了超过 20 个的 丝氨酸蛋白酶, 但只有少数的功能已经知道。烟草天蛾血 淋巴蛋白酶6和8（HP6 和HP8）各由一个氨基末端结构域和 羧基末端蛋白酶域组成。HP6 是果蝇PSH的同源物, 而HP8 与果蝇和黄粉虫的 spatzle激活酶高度相似, 这些都是激 活Tol1途径的。proHP6 和proHP8在脂肪体和血细胞中组成 
型表达并分泌到血浆中发挥作用, 被蛋白水解切割激活应 答微生物感染。proHP6接触革兰氏阴性或革兰氏阳性菌或 $\beta-1,3$-葡聚糖在血浆中变为活性形式然后激活proHP8, 这反过来又激活Spatzle-1，释放Spatzle-C108，羧基末 端 108 个残基的半胱氨酸结结构域的二聚体。注射 Spatzle-C108 (不是proSpatzle-1A) 到幼虫中, 能刺激 几个抗微生物肽和蛋白质, 包括Attacin-1, Cecropins -6 , moricin, 溶菌酶以及免疫球蛋白结构域蛋白hemolin的表 达。这表明Spatzle-C108二聚体可能在烟草天蛾中应答各 种微生物感染作为配体激活To11途径。SPZ结合在Tol1的N 末端主要诱导 2: 2络合物的形成, 细胞外相互作用的两条 链一条位于邻近的 $\mathrm{N}$ 末端的螺旋结构域, 另外一条位于 $\mathrm{C}$ 末端的近膜序列。此外, Tol1经历了配体诱导的构象变化, 变得更加紧密地弯曲 [22] [23]。

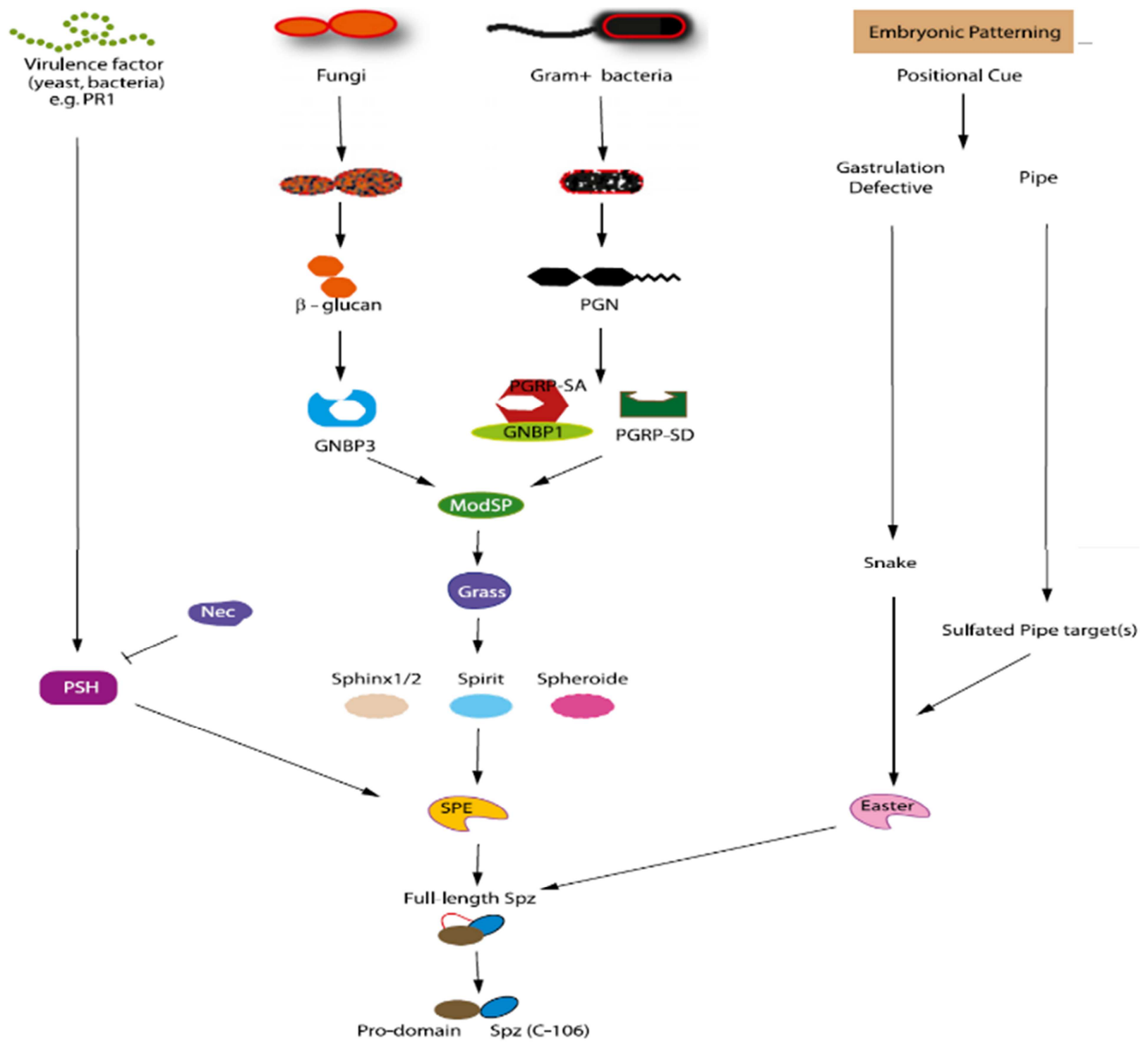

图1 果蝇spatzle的激活机制 [21]。

\section{3. 家蚕的spatzle}

家蚕 spatzle 家族共有6个成员，目前只有Bmspz1 [24] 和Bmspz4 [26]有所研究。Bmspz1基因在家蚕中作为Tol1 的配体激活Tol1信号通路, 超量表达Bmspz1可以诱导抗菌 肽的表达量上调, 表明家蚕 spatzle1也是作为Tol1受体的 配体参与免疫应答调节抗菌肽的表达 [24]。此外, Bmspz1 的全长 cDNA不能引起抗菌肽的表达, 而截短的Bmspz 1 能引 起抗菌肽的表达水平大大提高, 表明家虫的前 spatzle1 不具有活性, 只有裂解活化的 spatzle1才能引起免疫应答 [25]。Bmspz4基因的表达量能够由细菌和真菌的感染诱导
上调 [26]。家虫中的spatzle研究尚不完善, 其他spatzle 在免疫上功能还有待进一步研究。

\section{4. 其他昆虫的spatzle}

中国卤虫的spatzle4 cDNA全长已经被克隆出, 实时 苂光定量PCR和免疫组化检测显示在卤虫胚胎发育的各个 阶段spatzle的表达量不同，最高表达水平在胚胎发育的 7-10天。革兰氏阳性菌感染后 spatzle的转录水平逐渐增 加。免疫组化检测表明, spatzle主要表达于头胸部和胚 胎发育过程中消化道表面。它可能在发育早期阶段的背腹 
分化以及成虫阶段感染的免疫应答中发挥重要作用。卤虫 spatzle 的激活机制和果蝇 spatzle1相类似，两个前 spatzle的半胱氨酸通过二硫键结合形成同二聚体, 此二 聚体通过蛋白水解裂解以形成活性配体。卤虫 spatzlec 末端的活性部位是由 335 个氨基酸组成的C -335 , 与而果蝇 中的 C-106和烟草天蛾中的C-108不同。这种差异可能是由 于spatzle的mRNA的选择性剪接产生不同长度的多种亚型。 卤虫的spatzle 是这些亚型中的一种, 这个长的C一末端片 段可能不会影响其活性, 因为它的功能区域含有的半胱氨 酸结结构域, 这个功能结构域在其他物种中是保守的 [27]。

埃及伊蚊三个果蝇细胞因子 spatzle (Spz1A, 1B和1C) 的同源物从基因组和 $\mathrm{CDNA}$ 序列数据库中被确定。Spz1A 是 在脂肪体中由真菌感染特异性诱导。这种转录上调由REL1 介导的。Spz1C在脂肪体中组成型表达, 而Spz1B主要在雌 蚊卵巢组织中表达。RNA干扰敲除 Spz 1C 导致埃及伊文 To11/REL1（NF- K B 转录因子果蝇Dorsal的同源物）通路
的缺陷, 表明埃及伊蚊Spz1C 的功能在脂肪体中介导真菌 感染的免疫应答 $[28]$ 。

在冈比亚按蚊中, 六种果蝇spatzle (Spz1-6) 的同 源物在基因组中被鉴定 [29]。

目前已在多种生物中鉴定出 spz基因，对不同物种的 $\mathrm{spz}$ 基因编码的蛋白序列进行亲缘分析, 结果发现家虫、 意蜂、印度跳蚁、丽蝇蛹集金小蜂、踠豆蚜、埃及伊蚁、 果蝇、冈比亚按蚊、赤拟谷盗等昆虫的 $\mathrm{spz}$ 亲缘关系较近, 而与哺乳动物的 spz亲缘关系相对较远 (如图2)。对不同的 昆虫的 spz 同源蛋白的氨基酸保守序列进行比对, 发现赤 拟谷盗、冈比亚按蚊、埃及伊蚊、果蝇、烟草天蛾、家蚕 及踠豆长管蚜 $\mathrm{spz}$ 的氨基酸序列有 7 个相同的半胱氨酸同 源结构域（如图3）。表明昆虫 spz在进化上比较保守, 可 能具有相似的生物学功能, 为以后研究新的 spz提供理论 依据和研究思路。

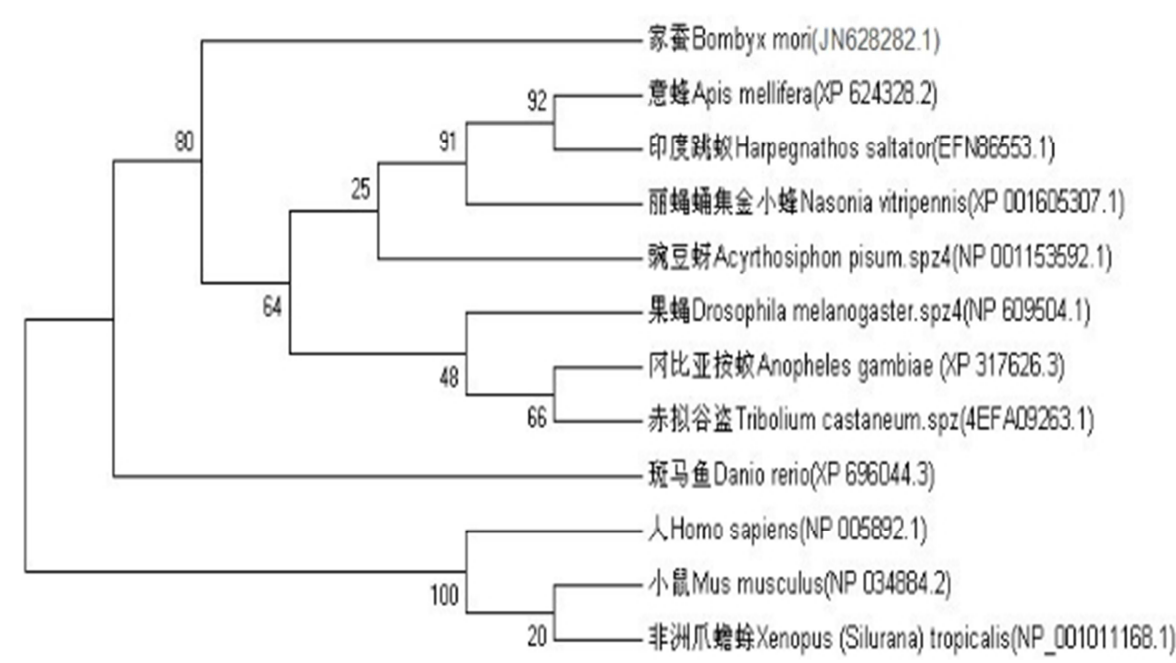

图2 不同物种spz同源蛋白序列的系统发生树。

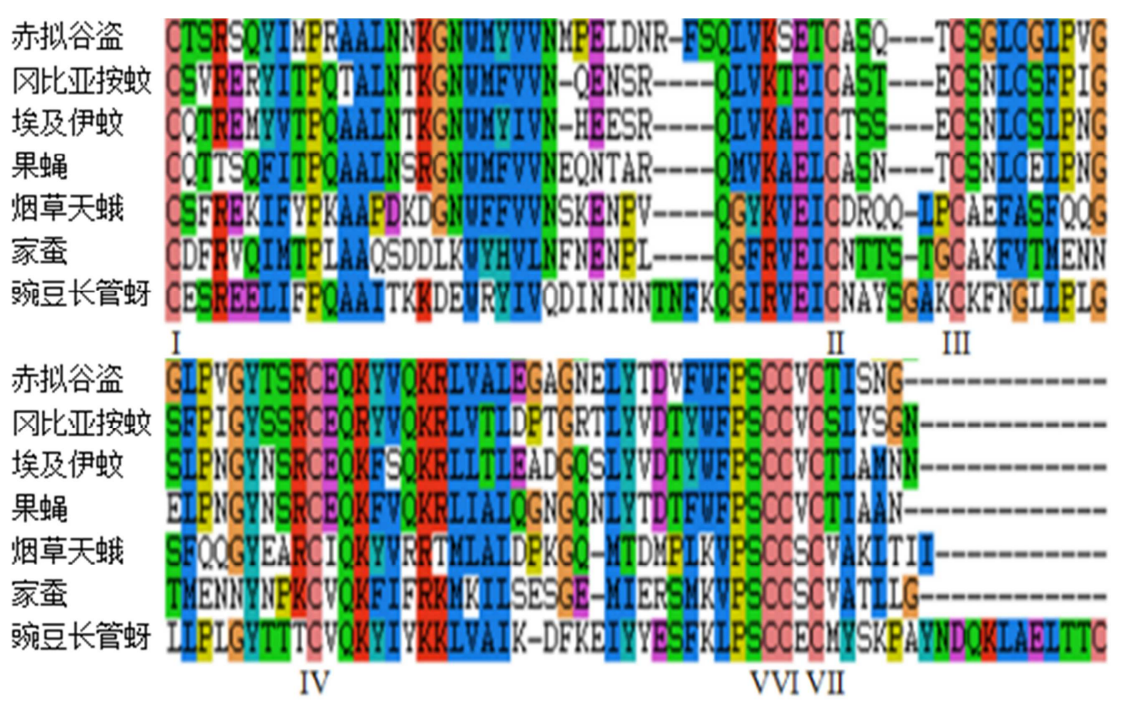

图3 不同昆虫spz同源蛋白的氨基酸保守序列比较。

Structure-guided sequence alignment of the cystine-knot domains of Spatzle homologues of insects. Tribolium castaneum, Anopheles gambiae, Aedes aegypti, Drosophila melanogaster, Manduca sexta, Bombyx mori, and Acyrthosiphon pisum. The core cystine-knot cystines are labelled I to VII. 


\section{Tol1信号通路的研究进展}

\section{1. 果蝇的Tol1信号通路}

Tol1信号传导通路是目前研究最多一条信号通路, 最 初在果蝇胚胎发育早期被鉴定, Tol1和Tol1样受体 (TLR) 在许多种动物中已经被确定。昆虫的Tol1信号传导途径与 哺乳动物的TLRs 信号传导途径经过长期的进化, 至今还 保留着惊人的相似性, 主要表现在Tol1受体和TLRs 结构 的相似以及相同的信号传递因子 (Myd88、TRAF6 、 Cactus) [30]。然而, 哺乳动物的TLRs功能只作为模式识 别受体, 在发育中没有发挥作用 [31]。而果蝇的Tol1通路 参与发育 $[32]$ 、免疫 $[33]$ 和C-Jun N-末端激酶（JNK）介 导的细胞死亡 $[34]$ 三个过程。

第一个Tol1受体在果蝇中发现, 它长期所知的功能是 胚胎背腹轴分化。果蝇胚胎背腹极性需要 spatzle-tol1 信号通路建立Dorsal蛋白的核梯度。这个梯度的形状在胚 胎中的改变由雌性携带 easter的显性等位基因产生。 easter基因编码一种丝氨酸蛋白酶激活spatzle作为Tol1 的配体。easter的显型等位基因越多核梯度的斜率越平。 在easter的显性等位基因胚胎提取物中, easter对应于自 由催化结构域, 这是从未在野生型中观察到的。这些突变 成显性等位基因的easter蛋白保留了蛋白酶活性, 能在胚 胎和在培养的果蝇细胞中加工spatzle [35]。

此外, 果蝇Tol1信号通路也参与控制革兰氏阳性细菌 和真菌的感染, 并在抑制口腔病毒感染方面发挥重要作用 [36]。Tol1激发一个进化上保守的信号通路，导致Re1家 族转录因子DIF的激活和后续许多基因的表达, 包括编码 抗真菌肽 [37]。跨膜受体Tol1的胞外域由结合配体的两个 富亮氨酸重复结构域构成。在果蝇中, 强烈的遗传证据表 明胚胎和成体中 Tol1的激活需要蛋白水解作用分泌的多 肽 spatzle（生长因子的半胱氨酸结家族）裂解形式的 spatzle作为Tol1的配体 [38]。果蝇Toll通路是Spatzle 被Spatzle加工酶 (SPE) 裂解后以释放出活性C-末端激活 的, spatzle被加工成其活性的 $\mathrm{C}$ 端 $\mathrm{C}-106$ 域的一个过程, 涉及丝氨酸蛋白酶级联活化。spatzle的蛋白水解导致构 象变化, 这暴露的 C-106域是结合To11至关重要的决定因 素 [39]。其然后结合至To11受体激活信号通路调控AMP基 因的表达（如图4）。在果蝇中, spatzle作为Tol1的直接 的细胞外配体从而激活To11 [40] [41]。相关To11样受体在 脊椎动物也起免疫的作用, 而是直接由病原体相关分子, 例如细菌内毒素激活 [42]。免疫反应的第一步是识别感染 信号, 即模式识别受体 (PRRs) 识别病原相关分子模式 (PAMPs) 激活免疫信号通路。有活性的spatzle配体结合激 活了跨膜受体Tol1, 活化的二聚体SPZ结合到一个Tol1胞 外域包围第一个 13 个亮氨酸重复区域。SPZ的胱氨酸结结 合在由 $\mathrm{N}-$ 连接的聚糖的 $t o 11$ 富含亮氨酸重复螺旋的凹面 并诱导构象变化形成稳定的二聚体 [43]。SPZ对 tol1的非 对称结合模式是与p75神经营养受体复合物中的神经生长 因子（NGF）类似的 [42] [44]。该二聚体Tol1复合物通过 细胞内的TIR(Toll-interleukin 1 resistance) 结构域
与衔接蛋白MyD88相互作用。MyD88招募Tube蛋白和细胞质 中丝氨酸/苏氨酸激酶Pelle, 哺乳动物 IL-1R相关激酶的 同源物, 形成 MyD88-Tube-Pe11e异源三聚体复合物通过 死亡域介导相互作用。细胞内信号导致 Cactus ( NF- $\mathrm{k} B$ 抑制剂 I K B 家族成员) 的磷酸化和降解, 释放Dorsal相关 免疫因子 (DIF) 和Dorsal, DIF和Dorsal转移到细胞核内 激活AMP基因的转录 [45]。果蝇的Tol1信号通路与哺乳动 物白介素 $-1(\mathrm{IL}-1 \mathrm{R})-\mathrm{NF}-\mathrm{kB}$ 信号通路是同源的信号通路,

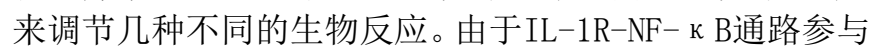
脊椎动物先天免疫, 且Tol1通路在植物中的同源通路在植 物抗病方面发挥重要作用, 该通路很有可能出现在植物和 动物的分化之前来抵抗病原物的入侵 [3]。

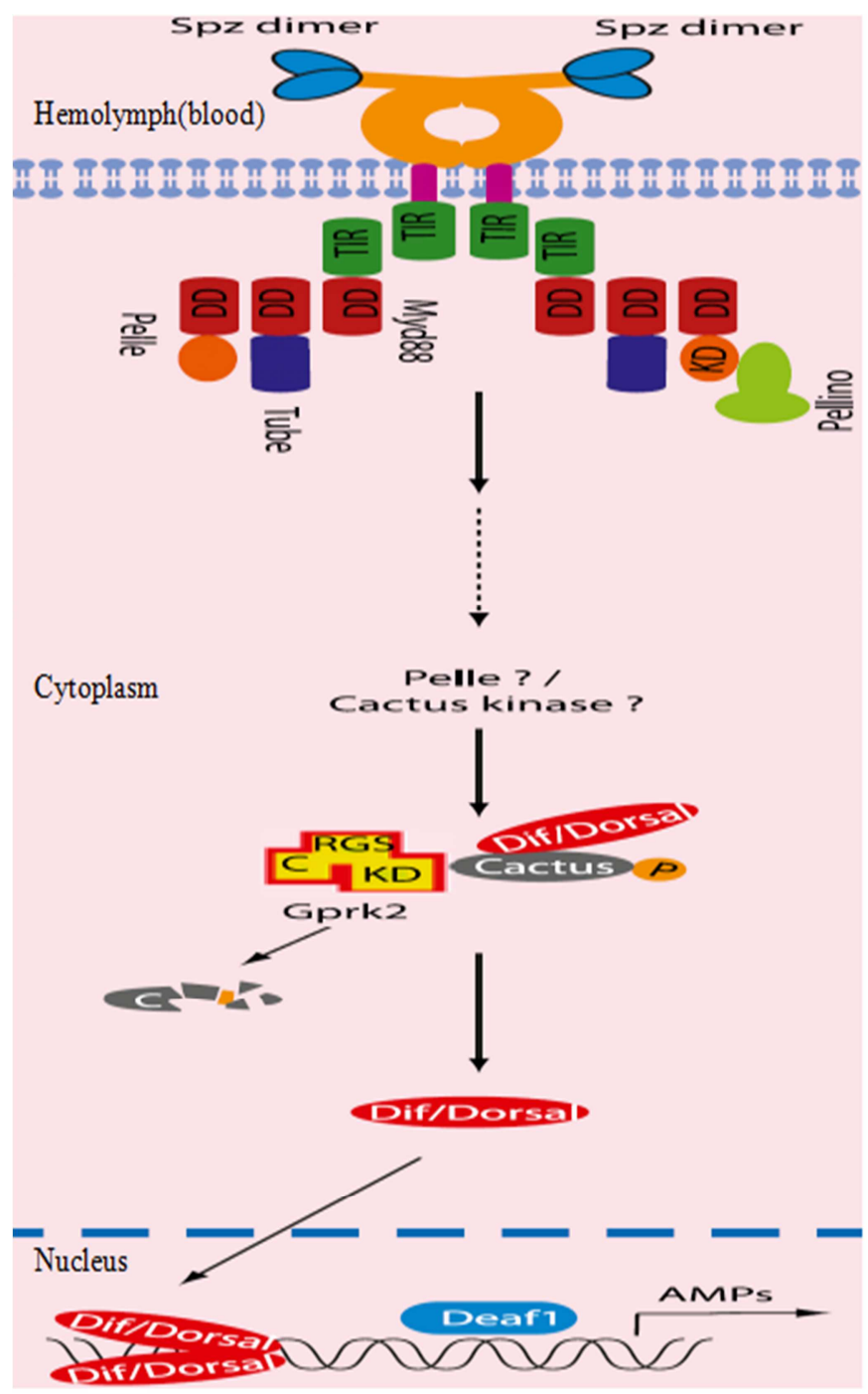

图4 果蝇To11信号通路 [21]。

新的研究发现果蝇Tol1通路参与JNK介导的细胞死亡。 Tol1信号的缺失抑制了 JNK信号诱导的细胞死亡的生理活 化。Tol1通路作为JNK依赖的细胞死亡的下游调节。另外, JNK 信号的获得同样诱导 Tol1通路的激活, 表现为 Drosomycin (DRS) 的刺激转录、Dorsal从细胞质至细胞 核易位的增加和 spz家族配体的转录上调 [34]。 


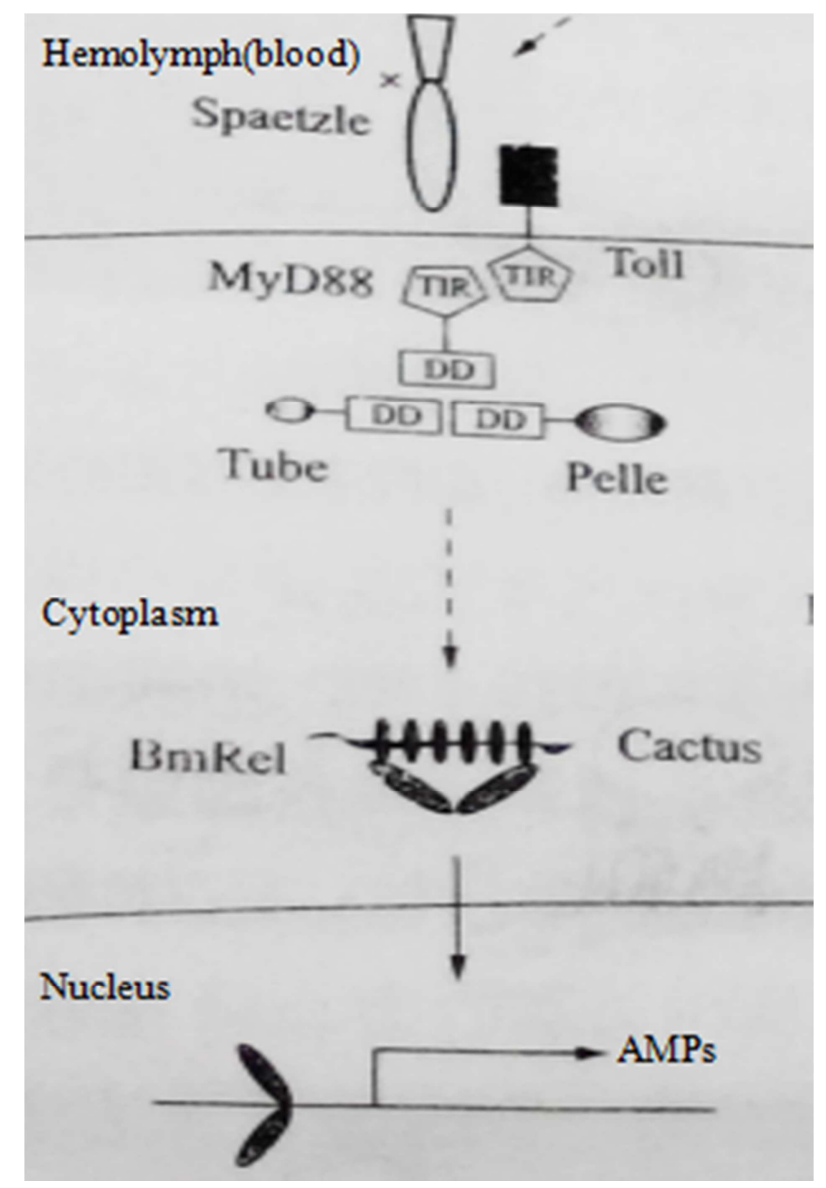

图5 家虫To11信号通路。

\section{2. 烟草天蛾的Tol1信号通路}

研究表明, 烟草天蛾中也存在To11信号通路。Toll 信号通路激活途径的分子机制表明前Spatzle前结构域掩 盖了非常重要的spatzle的疏水性区域和该蛋白水解导致 暴露的构象变化表明是结合于Toll受体的关键。此外, 一 个前结构域保守序列呈现出两亲性螺旋可能绑定在 spatzle从而阻断与To11受体的结合。Tol1的组成型活性 突变体的多聚体包含分子间二硫键, 这些二硫键是这些突 变受体活性的关键, 这表明多聚化是组成型活性必不可少 的。此外, 系统的突变分析表明, 一个保守的包含半胱氨 酸的基序, 与用于分子间二硫键的半胱氨酸不同, 是作为 Tol1的一个自我抑制模块, 该半胱氨酸基序的删除或突变 导致Tol1的激活。单独的含有半胱氨酸的基序可能提供结 构信息来调节该受体的多聚化及活性。这一基序位于跨膜 区外, 并可以提供To11的多聚化和激活的结构性障碍。总 之, 多聚化可能是To11受体激活的调节的必要步骤 [46]。 与果蝇的SPZ-To11通路类似, 免疫共沉淀实验表明, 烟草 天蛾Tol1的胞外结构域能与烟草天蛾spatzle (MsSPZ) 的 活跃C端C108结构域(而不是全长MsSPZ) 相互作用。这表明 MsTo11-MsSpz-C108复合物可激活To11信号通路。体内测 定表明, 通过纯化的重组MsSPZ-C108-MsTol1, 使AMP基因, 包括 cecropin、Attacin, moricin和lebocin在烟草天蛾 幼虫中的激活, 进一步确认了烟草天蛾中存在To11-SPZ 通路 [44]。

\section{3. 家蚕的 Tol1信号通路}

家蚕含有与果䗉同源的Tol1受体、Spatzle配体、模 式识别受体PGRP、抗菌肽Cecropin和Attacin、以及NF-KB 类转录调控因子 Rel和Relish等同源基因。家䖯的模式识 别受体 $\beta$ GRP3 能特异性地识别革兰氏阳性细菌, 具有激 活抗菌肽基因表达的生物学功能。对Tol1信号通路相关 基因的鉴定和功能研究, 发现家䖯抗菌肽基因表达调控 分子机制比较保守。Spatzle1被激活后结合并激活Toll 受体, 接着通过细胞内的TIR结构域与衔接蛋白MyD88相 互作用, MyD88招募Tube蛋白和细胞质中丝氨酸/苏氨酸 激酶Pe1le 形成 MyD88-Tube-Pe1le 异源三聚体导致 Cactus 的磷酸化和降解, 释放出Re1最终激活AMP基因的 转录 [26]（如图5）。

\section{4. 结语}

不同物种的 spatzle 具有相似的保守的半胱氨酸结构 域, 在免疫应答中发挥相同的作用, 能够被微生物诱导表 达并调控抗菌肽的表达。由此可见, Spatzle作为Toll受 体的配体在免疫应答的起始发挥重要作用, 具有十分重要 的研究意义。阐释spatzle在先天免疫应答中调控的分子 机制对提高家蚕的抗病性以及增强生物杀虫剂的杀虫效 率等方面有重要意义。相信Spatzle及Toll通路的深入研 究将为保护益虫防治害虫、保护我们的生态环境做出贡献。

\section{致谢}

本文由中国国家自然科学基金项目 (31272508) 支持。

\section{参考文献}

[1] 吕鸿声. 昆虫免疫学原理 [M]. 上海: 上海科学技术出版社, 2008. $12: 20$ 。

[2] 张明明, 初源, 赵章武, 安春菊. 昆虫天然免疫反应分子机制 研究进展 $[J]$. 昆虫学报, 2012, 55 (10)：1221-1229。

[3] Marcia P, Belvin, Kathryn V Anderson. A conserved signaling pathway: The Drosophila Toll-Dorsal Pathway[J]. Cell Dev Biol, 1996, 12:393-416.

[4] Medzhitov R, Janeway C Jr. Innate immune recognition: mechanisms and pathways[J]. Immunol Rev, 2000, 173, 89-97.

[5] Janeway CA Jr. Approaching the asymptote Evolution and revolution in immunology[J]. Cold Spring Harb Symp Quant Biol, 1989. 54: 1-13.

[6] James S. Parker, Kenji Mizuguchi, and Nicholas J. Gay. A Family of Proteins Related to Spatzle, the Toll Receptor Ligand, Are Encoded in the Drosophila Genome [J]. PROTEINS: Structure, Function, and Genetics, 2001, 45: 71-80. 
[7] Ming M, Obata F, Kuranaga E, Miura M. Persephone/Spätzle pathogen sensors mediate the activation of Toll receptor signaling in response to endogenous danger signals in apoptosis-deficient Drosophila [J]. J Biol Chem. 2014. 289(11) : 7558-68.

[8] Hoffmann A, Funkner A, Neumann P et al. Biophysical characterization of refolded Drosophila Spatzle, a Cystine Knot Protein, Reveals Distinct Properties of Three Isoforms[J]. J Biol Chem, 2008, Nov 21; 283 (47) : 32598-609.

[9] Christopher J. Arnot, Nicholas J. Gay, and Monique Gangloff. Molecular Mechanism That Induces Activation of Spatzle, the Ligand for the Drosophila Toll Receptor [J]. THE JOURNAL OF BIOLOGICAL CHEMISTRY, 2010, 25, 19502-19509.

[10] Weber AN, Tauszig-Delamasure S, Hoffmann JA et al. Binding of the Drosophila cytokine Spätzle to Toll is direct and establishes signaling $[J]$. Nat Immunol, 2003, 4(8) : 794-800.

[11] LeMosy EK, Tan YQ, Hashimoto C. Activation of a protease cascade involved inpatterning the Drosophila embryo[J]. Proc Natl Acad Sci USA, 2001, 98: $5055-5060$.

[12] Cho, Y. S., L. M. Stevens, and D. Stein. Pipe-dependent ventral processing of Easter by Snake is the defining step in Drosophila embryo DV axis formation[J]. Curr. Biol. 2010. 20: $1133-1137$.

[13] David Stein, Iphigenie Charatsi, Yong Suk Cho, Zhenyu Zhang, Jesse Nguyen, Robert DeLotto, Stefan Luschnig, and Bernard Moussian. Localization and Activation of the Drosophila Protease Easter Require the ER-Resident Saposin-like Protein Seele [J]. Current Biology, 2010, 20, 1953-1958.

[14] Gobert V, Gottar M, Matskevich A. Dual activation of the Drosophila toll pathway by two pattern recognition receptors $[J]$. Science, 2003, 302 (5653) : 2126-2130.

[15] El Chamy, L., V. Leclerc, I. Caldelari, and J. M. Reichhart. Sensing of ' danger signals' and pathogen-associated molecular patterns defines binary signaling pathways 'upstream' of Toll $[\mathrm{J}]$. Nat. Immunol. 2008. 9: 1165-1170.

[16] Kambris, Z., S. Brun, I. H. Jang, H. J. Nam, Y. Romeo, K. Takahashi, W. J. Lee, R. Ueda, and B. Lemaitre. Drosophila immunity: a large-scale in vivo RNAi screen identifies five serine proteases required for Toll activation[J]. Curr. Biol. 2006. 16:808-813.

[17] Buchon, N., M. Poidevin, H. M. Kwon, A. Guillou, V. Sottas, B. L. Lee, and B. Lemaitre. A single modular serine protease integrates signals from pattern-recognition receptors upstream of the
Drosophila Toll pathway[J]. Proc. Natl. Acad. Sci. USA . 2009. 106: $12442-12447$.

[18] Gottar, M., V. Gobert, A. A. Matskevich, J. M. Reichhart, C. Wang, T. M. Butt, M. Belvin, J. A. Hoffmann, and D. Ferrandon. Dual detection of fungal infections in Drosophila via recognition of glucans and sensing of virulence factors [J]. Ce11. 2006. 127: $1425-1437$.

[19] Nad è ge Peltea, Andrew S. Robertsonb, Zhen Zouc, Didier Belorgeyb, Timothy R. Daffornd, Haobo Jiangc, David Lomase, Jean-Marc Reichharta, and David Gubbf. Immune challenge induces $\mathrm{N}$-terminal cleavage of the Drosophila serpin Necrotic [J]. Insect Biochem Mol Biol, 2006 , 36(1): 37-46.

[20] Yamamoto-Hino M, Muraoka M, Kondo S, Ueda R, Okano H, Goto S. Dynamic regulation of innate immune responses in Drosophila by Senju-mediated glycosylation [J]. Proc Natl Acad Sci U S A. 2015. 112 (18) : 5809-14.

[21] Susanna Valanne, Jing-Huan Wang and Mika Rämet. The Drosophila Toll Signaling Pathway[J]. Immunol 2011. 186: 649-656.

[22] An C, Jiang H, Kanost MR. Proteolytic activation and function of the cytokine Spatzle in the innate immune response of a lepidopteran insect, Manduca sexta[J]. FEBS, 2010, 277(1) : 148-162.

[23] Chunju An, Jun Ishibashi, Emily J. Ragan, Haobo Jiang, and Michael R. Kanost. Functions of Manduca sexta Hemolymph Proteinases HP6 and HP8 in Two Innate Immune Pathways $[\mathrm{J}]$. THE JOURNAL OF BIOLOGICAL CHEMISTRY, 2009, 29, 19716-19726.

[24] Taniai K, Ishii T, Sugiyama M. Nucleotide sequence of 5' -upstream region and expression of a silkworm gene encoding a new member of the attacin family[J]. Biochem Biophys Res Commun, 1996, 220 (3) : 594-599.

[25] Wang Y, Cheng T, Rayaprolu S et al. Proteolytic activation of pro-spatzle is required for the induced transcription of antimicrobial peptide genes in lepidopteran insects[J]. Dev Comp Immunol, 2007, 31 (10) : 1002-1012.

[26] 徐颖. 家蚕新的免疫基因Spatzle克隆与功能及假单胞菌致 病性研究 [D]. 镇江: 江苏科技大学硕士学位论文, 2012。

[27] Lu ping Zheng, Lin Hou, Miao Yu, Xiang Li, Xiang-yang Zou. Cloning and the expression pattern of Spatzle gene during embryonic development and bacterial challenge in Artemia sinica[J]. Mol Biol Rep, 2012, 39: 6035-6042.

[28] Sang Woon Shin, Guowu Bian, and Alexander S. Raikhel. A Toll Receptor and a Cytokine, Tol15A and Spz1C, Are Involved in Toll Antifungal Immune Signaling in the Mosquito Aedes aegypti[J]. THE JOURNAL OF BIOLOGICAL CHEMISTRY. 2006, 51, 39388-39395. 
[29] Christophides, G. K. , Zdobnov, E., Barillas-Mury, C. , Birney, E., Blandin, S., Blass, C., Brey, P. T., Collins, F. H., Danielli, A., Dimopoulos, G., Hetru, C., Hoa, N. T., Hoffmann, J. A., Kanzok, S. M., Letunic I. , Levashina, E. A., Loukeris, T. G., Lycett, G., Meister, S., Michel, K., Moita, L. F., Muller, H. M., Osta, M. A., Paskewitz, S. M., Reichhart, J. M. , Rzhetsky, A., Troxler, L., Vernick, K. D., Vlachou, D., Volz, J., von Mering, C., Xu, J., Zheng, L., Bork, P., and Kafatos, F. C. Immunity-related genes and gene families in Anopheles gambiae[J]. Science. 2002, 298, 159-165.

[30] 黎群英, 张涛, 张传博. 昆虫Tol1受体及其研究进展 $[\mathrm{J}]$. 贵州农业科学. 2008, 36 (6) :67-69。

[31] Kimbrel1 D. A, Beutler B. The evolution and genetics of innate immunity[J]. Nat Rev Genet, 2001, 2: 256-267.

[32] Halfon M. S, Hashimoto C, Keshishian H. The Drosophila toll gene functions zygotically and is necessary for proper motoneuron and muscle development $[\mathrm{J}]$. Dev Biol, 1995, 169: 151-167.

[33] Lemaitre B, Nicolas E, Michaut L et al. The dorsoventral regulatory gene cassette spatzle/Toll/cactus controls the potent antifungal response in Drosophila adults[J]. Cel1, 1996, 86: 973-983.

[34] Wu C, Chen C, Dai J, Zhang F, Chen Y, Li W, Pastor-Pareja JC, Xue L. Toll pathway modulates TNF-induced JNK-dependent cell death in Drosophila [J]. Open Biol. 2015. 5(7): 140171.

[35] Andy J. Chang and Donald Morisato. Regulation of Easter activity is required for shaping the Dorsal gradient in the Drosophila embryo[J]. Development, 2002, 129, 5635-5645.

[36] Ferreira ÁG, Naylor H, Esteves SS, Pais IS, Martins NE, Teixeira L. The Toll-dorsal pathway is required for resistance to viral oral infection in Drosophila [J]. PLoS Pathog. 2014. 10 (12) : e1004507.

[37] De Gregorio E, Spellman PT, Tzou P. The Toll and Imd pathways are the major regulators of the immune response in Drosophila[J]. EMB0, 2002, 21: 2568 2579 .

[38] Mizuguchi K, Parker JS, Blundell TL. Getting knotted: a model forthe structure and activation of Spatzle[J]. Trends Biochem Sci, 1998, 23: $239-242$.

[39] Arnot CJ, Gay NJ, Gangloff M. Molecular mechanism that induces activation of Spatzle, the ligand for the Drosophila toll receptor $[J]$. Biol Chem, 2010, 285: 19502-19509.

[40] Xue Zhong, Xiao-Xia Xu. A Tol1-Spätzle pathway in the tobacco hornworm, Manduca sexta[J]. Insect Biochemistry and Molecular Biology, 2012, 42: 514-524.

[41] Valanne S, Wang JH, Ramet M. The Drosophila Toll signaling pathway[J]. Immunol, 2011, 186: 649-656.

[42] Miranda Lewisa, Christopher J. Arnota, Helen Beestonb, Airlie McCoyc, Alison E. Ashcroftb, Nicholas J. Gaya, and Monique Gangloffa. Cytokine Spätzle binds to the Drosophila immunoreceptor Toll with a neurotrophin-like specificity and couples receptor activation[J]. Proc Natl Acad Sci U S A. 2013, 17, $110(51):$ 20461-20466.

[43] Parthier C, Stelter M, Ursel C, Fandrich U, Lilie H, Breithaupt C, Stubbs MT. Structure of the Toll-Spatzle complex, a molecular hub in Drosophila development and innate immunity $[\mathrm{J}]$. Proc Natl Acad Sci U S A. 2014. 111(17): 6281-6.

[44] Hu X, Yagi Y, Tanji T et al. Multimerization and interaction of Toll and Spatzle in Drosophila[J]. Proc. Natl Acad Sci USA, 2004, 101: 9369-9374.

[45] Moncrieffe MC, Grossmann JG, Gay NJ. Assembly of oligomeric death domain complexes during Toll receptor signaling[J]. Biol Chem, 2008, 283: 33447-33454.

[46] Kanost MR, Jiang H, Yu XQ. Innate immune responses of a lepidopteran insect, Manduca sexta[J]. Immunol Rev, 2004, 198: 97-105. 